\title{
First observations of attempted nudibranch predation by sea anemones
}

\author{
Sancia E. T. van der Meij • Bastian T. Reijnen
}

Received: 18 April 2011 /Revised: 1 June 2011 / Accepted: 6 June 2011 /Published online: 24 June 2011

(C) The Author(s) 2011. This article is published with open access at Springerlink.com

\begin{abstract}
On two separate occasions during fieldwork in Semporna (eastern Sabah, Malaysia), sea anemones of the family Edwardsiidae were observed attempting to feed on the nudibranch species Nembrotha lineolata and Phyllidia ocellata. These are the first in situ observations of nudibranch predation by sea anemones. This new record is compared with known information on sea slug predators.
\end{abstract}

Keywords Actiniaria Coral reef - Nudibranchia .

Polyceridae $\cdot$ Phylidiidae

\section{Introduction}

Several organisms are known to prey on sea slugs (Gastropoda: Opisthobranchia), including fish, crabs, worms and sea spiders (e.g. Trowbridge 1994; Rogers et al. 2000; Arango and Brodie 2003). The available information on sea slug predators nevertheless remains scarce (Rudman 2000).

Herein we report the first in situ observations of reefdwelling sea anemones (Anthozoa: Actiniaria) attempting to feed on nudibranchs. There are no previous field observations of nudibranch predation by sea anemones, except for two records obtained through aquarium experiments (Thompson 1960; Bryan et al. 1998).

S. E. T. van der Meij $(\bowtie) \cdot$ B. T. Reijnen

Department of Marine Zoology, Netherlands Centre for

Biodiversity Naturalis,

P.O. Box 9517, 2300 RA Leiden, The Netherlands

e-mail: sancia.vandermeij@ncbnaturalis.nl

\section{Material and methods}

The observations were made during fieldwork on coral reefs in the Semporna district (eastern Sabah, Malaysia), as part of the Semporna Marine Ecological Expedition in December 2010 (SMEE2010). The reported observations were made on Creach Reef $\left(04^{\circ} 18^{\prime} 58.8^{\prime \prime} \mathrm{N}, 118^{\circ} 36^{\prime} 17.3^{\prime \prime}\right.$ E) and Pasalat Reef $\left(04^{\circ} 30^{\prime} 47.8^{\prime \prime} \mathrm{N}, 118^{\circ} 44^{\prime} 07.8^{\prime \prime} \mathrm{E}\right)$, at approximately $10 \mathrm{~m}$ depth for both observations. The nudibranch identifications were checked against Gosliner et al. (2008), whereas the identification of the sea anemone was done by A. Crowther. No material was collected. Photos were taken with a Canon 400D with a Sigma 50-mm macro lens.

\section{Results}

A reef-dwelling anemone, belonging to a species of the family Edwardsiidae, was observed on Creach Reef while attempting to feed on a nudibranch of the species Nembrotha lineolata Bergh, 1905 (family Polyceridae). On discovery, the nudibranch was ingested from its tail to gills (Fig. 1a) with the sea anemone's mouth protruding around the nudibranch. The nembrothid was stretching its body and reaching in the direction of the sandy substrate (Fig. 1b-c). Meanwhile, the actininarian's tentacles touched the nudibranch, making it flinch upon contact before continuing to stretch. Eventually, the nembrothid managed to pull itself free, leaving behind a thick mucus trail (Fig. 1d), while visually appearing unharmed (Fig. 1e). Subsequently, the anemone's oral disc slowly retracted. The total observation time was about $7 \mathrm{~min}$ (Fig. 1a-e). 

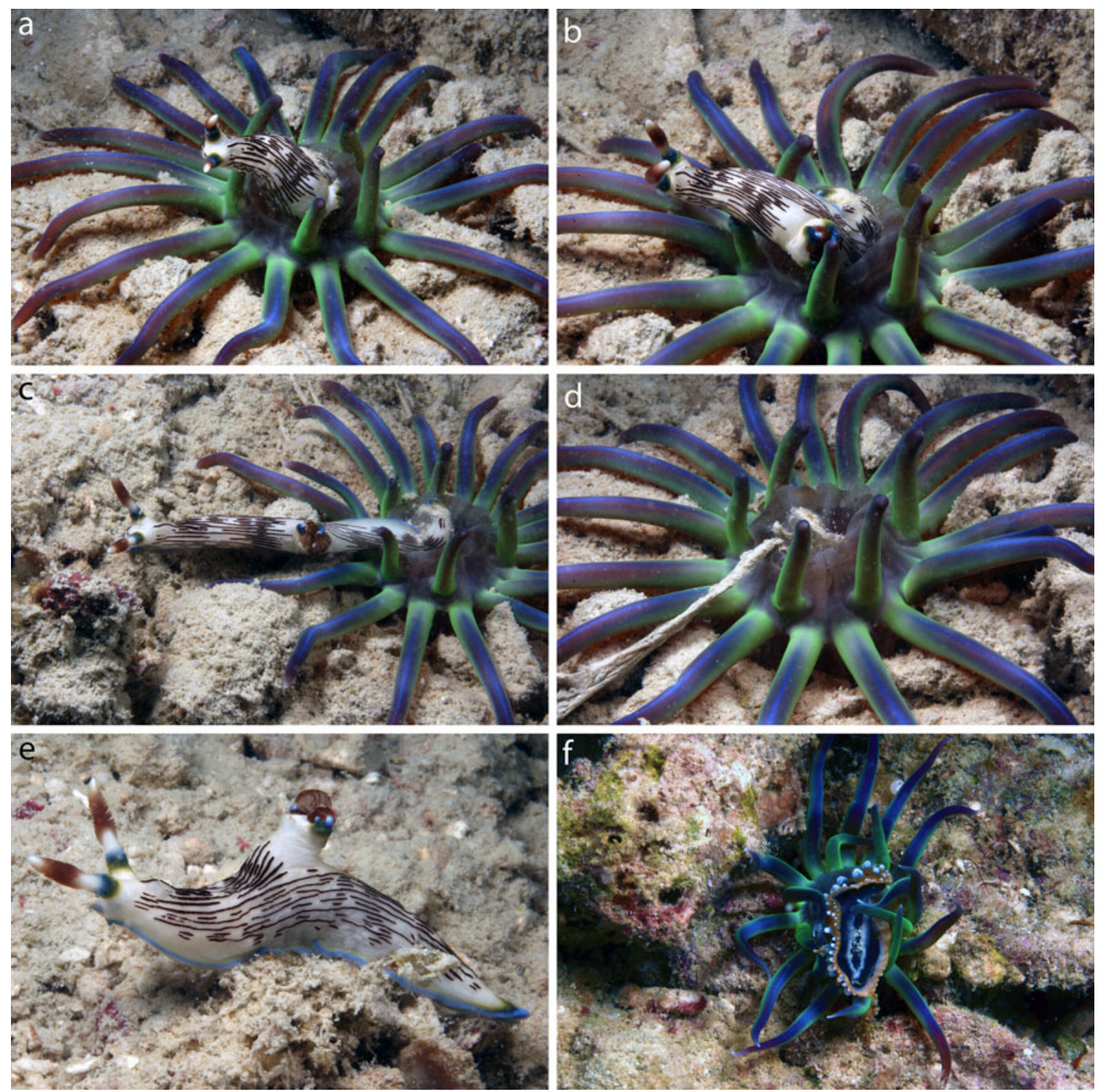

Fig. 1 a-e The unsuccessful attempt of an edwardsiid sea anemone to feed on a Nembrotha lineolata. f A non-responsive Phyllidia ocellata caught by the tentacles of an edwardsiid sea anemone

On a separate occasion, on Pasalat Reef, a different specimen of presumably the same edwardsiid species was observed holding a Phyllidia ocellata (Cuvier, 1804) (family Phylidiidae) upside down (Fig. 1f). The nudibranch was not responding to the sea anemone's tentacles and appeared paralyzed or dead. The sea anemone was actively moving its tentacles, suggesting movement of its prey into the gastrovascular cavity. It is unknown if the ingestion was concluded successfully. The observation time was about $1 \mathrm{~min}$.

\section{Discussion}

Sea slugs, informally grouped as the Opisthobranchia, are subdivided into numerous (sub-)clades, including the Aply- siomorpha (sea hares), Sacoglossa (sap-sucking slugs), and the large subclade of the Nudibranchia (true nudibranchs) (Bouchet and Rocroi 2005). Predation by sea anemones has only been reported for the Aplysiomorpha (e.g. Winkler and Tilton 1962; Johnson and Willows 1999). For the Sacoglossa there are records of predatory attacks by other sea slugs, as well as feeding experiments with fish and crabs (Trowbridge 1994). The majority of the predation records for the subclade Nudibranchia consist of attacks by other sea slugs (Rudman 2000).

Sea anemones are sedentary organisms, and are considered opportunistic feeders; their diet includes crabs, fish, sea urchins and zooplankton (Ruppert et al. 2004). The sea anemone in Fig. 1 is identified as belonging to the family Edwardsiidae, although it has been erroneously referred to as Condylactis sp. (e.g. Colin and Arneson 1995: fig. 565; 
Fosså and Nilsen 1998: p. 240). Edwardsiid sea anemones are common elements of the benthic marine infauna, but the Pacific actiniarian fauna is poorly known (Daly and Ljubenkov 2008). It is unclear whether nudibranchs form a major part of their diet. Dozens of other edwardsiid anemones were observed over the course of the 3 -week fieldwork period, not increasing the number of predation records. The attempted predation of a phyllidid nudibranch is surprising because sea slugs of the Phyllidiidae are known to be toxic (Fusetani et al. 1992).

Acknowledgements We would like to thank Andrea Crowther (University of Kansas) for her help in identifying the sea anemone. SMEE2010 was jointly organized by WWF-Malaysia, Universiti Malaysia Sabah's Borneo Marine Research Institute, Universiti Malaya's Institute of Biological Sciences and the Netherlands Centre for Biodiversity Naturalis. Research permission was granted by Economic Planning Unit, Prime Minister's Department, Economic Planning Unit Sabah, Sabah Parks and Department of Fisheries Sabah. Three anonymous reviewers provided valuable comments on the manuscript.

Open Access This article is distributed under the terms of the Creative Commons Attribution Noncommercial License which permits any noncommercial use, distribution, and reproduction in any medium, provided the original author(s) and source are credited.

\section{References}

Arango CP, Brodie GD (2003) Observations of predation on the tropical nudibranch Okenia sp. by the sea spider Anoplodactylus longiceps Williams (Arthropoda: Pycnogonida). Veliger 46:99-101

Bergh LSR (1905) Die Opisthobranchiata der Siboga-Expedition. Monographie 50. Brill, Leiden, pp 1-248

Bouchet P, Rocroi J-P (2005) Classification and nomenclature of gastropod families. Malacologia 47:1-397

Bryan PJ, McClintock JB, Baker BJ (1998) Population biology and antipredator defenses of the shallow-water Antarctic nudibranch Tritoniella belli. Mar Biol 132:259-265
Colin PL, Arneson C (1995) Tropical Pacific invertebrates-a field guide to the marine invertebrates occurring on tropical Pacific coral reefs, seagrass beds and mangroves. Coral Reef Press, Beverly Hills

Cuvier GL (1804) Mémoire sur la Phyllidie et sur le Pleurobranche, deux nouveaux genres de mollusques de l"ordre des gastéropodes, et voisins des patelles et des oscabrions, dont l'un est nu dont l'autre porte une coquille cachée. Annales du Muséum National d'Histoire Naturelle, Paris 5:266-276

Daly M, Ljubenkov JC (2008) Edwardsiid sea anemones of California (Cnidaria: Actiniaria: Edwardsiidae), with descriptions of eight new species. Zootaxa 1860:1-27

Fosså SA, Nilsen AJ (1998) The modern coral reef aquarium, vol 3. Birgit Schmettkamp, Bornheim

Fusetani N, Wolstenholme HJ, Shinoda K, Asai N, Matsunaga S, Onuki H, Hirota H (1992) Two sesquiterpene isocyanides and a sesquiterpene thiocyanate from the marine sponge Acanthella $\mathrm{cf}$. cavernosa and the nudibranch Phyllidia ocellata. Tetrahedron Lett 33:6823-6826

Gosliner TM, Behrens DW, Valdés Á (2008) Indo-Pacific nudibranchs and sea slugs. A field guide to the world's most diverse fauna. Sea Challengers Natural History Books, Washington

Johnson PM, Willows AO (1999) Defense in sea hares (Gastropoda, Opisthobranchia, Anaspidea): multiple layers of protection from egg to adult. Mar Freshw Behav Physiol 32:147-180

Rogers CN, de Nys R, Steinberg PD (2000) Predation on juvenile Aplysia parvula and other small anaspidean, ascoglossan and nudibranch gastropods by pycnogonids. Veliger 43:330-337

Rudman WB (2000) What eats sea slugs? In: Sea Slug Forum. Australian Museum, Sydney. Available from http://www.seaslugforum.net/ factsheet/predrecord

Ruppert EE, Fox RS, Barnes RD (2004) Invertebrate zoology: a functional evolutionary approach, 7th edn. Brooks/Cole-Thompson, Belmont

Thompson TE (1960) Defensive adaptations in opisthobranchs. J Mar Biol Assoc UK 39:123-134

Trowbridge CD (1994) Defensive responses and palatability of specialist herbivores: predation on N.E. Pacific ascoglossan gastropods. Mar Ecol Prog Ser 105:61-70

Winkler LR, Tilton BE (1962) Predation on the California sea hare, Aplysia californica Cooper, by the solitary great green sea anemone, Anthopleura xanthogrammica (Brandt), and the effect of sea hare toxin and acetylcholine on anemone muscle. Pac Sci $16: 286-290$ 